\title{
Byssinosis : a follow-up study of workers exposed to fine grade cotton dust
}

\author{
FEDOR VALIĆ and EUGENIJA ŽUSKIN \\ Andrija Stampar School of Public Health, Zagreb University, Zagreb, Yugoslavia
}

\begin{abstract}
A follow-up study was made in a group of cotton workers processing fine grade cotton fibres. Respiratory symptoms and ventilatory capacity were first recorded in 1962 and later in 1971. In 1962, 20 men and 23 women were examined whereas in 1971 only 15 of the men and 13 of the women were still in the mill. In 1962 no case of byssinosis was recorded. The prevalence of chronic cough and chronic bronchitis was higher among men than women. In 1971 the incidence of byssinosis was $20 \%$ in men and $23 \%$ in women and the prevalence of all other respiratory symptoms had also increased.

In men there was a significant mean decrease of the forced expired volume in $0.75 \mathrm{sec}$ $\left(\mathrm{FEV}_{0.75}\right)$ over the shift both in $1962(\mathrm{P}<0.05)$ and in $1971(\mathrm{P}<0.01)$. In women the mean acute decrease of $\mathrm{FEV}_{0.75}$ over the shift in 1962 was not statistically significant $(P>0.05)$, but in 1971 it was $(P<0.05)$. The mean acute reductions of $F E_{0.75}$ were considerably higher in 1971 than in 1962. In byssinotics these changes were considerably higher than in non-byssinotics. The chronic effect on ventilatory capacity of exposure to fine cotton dust was not observed in this study.
\end{abstract}

Although there have been numerous reports on the effects of vegetable dust on the respiratory system, and particularly on the effect of exposure to cotton dust, there have been very few longterm follow-up studies on the same population sample exposed to the same vegetable dust for many years (Molyneux and Tombleson, 1970). No follow-up studies have been reported on a population exposed to the dust of fine grade cotton. We are therefore reporting the results of examinations carried out in 1962 and 1971 of a group of male and female textile workers in a small mill processing fine grade cotton.

\section{POPULATION AND METHODS}

In 1962 a group of 20 men and 23 women were examined. The mean age of the men was 27 , ranging from 19 to 37 years, and the mean duration of exposure to cotton dust was $2 \cdot 5$, ranging from 1 to 3 years. The mean age of the women was 24 , ranging from 17 to 35 years, and the mean duration of exposure to cotton dust was 1.7, ranging from 1 to 3 years.

In 1971 only 15 men and 13 women of those examined in 1962 were still working in the mill. All were studied.

RESPIRATORY SYMPTOMS Respiratory symptoms, smoking habits, and occupational histories were re- corded, using the British Medical Research Council questionnaire on chronic bronchitis supplemented by questions on symptoms of byssinosis (Schilling et al., 1964).

Chronic cough or phlegm: cough or phlegm production on most days for at least three months in the year.

Chronic bronchitis: cough and phlegm on most days for a minimum of three months in the year and for not less than two successive years.

Dyspnoea grade 2: shortness of breath when hurrying or walking up a slight hill; grade 3 , shortness of breath when walking with other people at an ordinary pace on the level.

Byssinosis grade 1/2: occasional chest tightness or difficulty in breathing on the first working day in the week or after an absence of more than two days ; grade 1, chest tightness or difficulty in breathing on every first working day in the week or after an absence of more than two days.

VENTILATORY FUNCTION The forced expiratory volume over 0.75 second $\left(F^{2} V_{0.75}\right)$ was measured using a spirometer with an electronic timer similar to that described by McKerrow, McDermott, and Gilson (1960). The FEV 0.75 was measured before and after the work shift on the first working day after a break of exposure to cotton dust of more than two days. On every occasion five measurements were made; the mean of the two highest values was taken as the result of the test and corrected to 
BTPS. The spirometer was calibrated before and after testing each group of workers.

The $\mathrm{FEV}_{0.75}$ values can be converted approximately to $\mathrm{FEV}_{1.0}$ units by the conversion formula (McKerrow et al., 1960): $\mathrm{FEV}_{1.0} \quad$ (litres) $=1.08$ FEV $_{0 \cdot 75}$ (litres)+0.09.

DUST SAMPLING Airborne dust was sampled with the Hexhlet two-stage sampler (Wright, 1954). Dust concentrations were expressed separately for total and respirable dust fractions, the latter being defined, in conformity with the requirements of the British Medical Research Council for particle retention in the upper respiratory tract (Orenstein, 1960), as the particle size fraction that passes the horizontal laminar plate elutriator.

Twenty-eight airborne dust samples were collected throughout the work shift during two weeks in 1962 and 30 samples during the same period in 1971.

\section{RESULTS}

DUST CONCENTRATIONS The mean total airborne cotton dust concentration to which the examined workers were exposed was $1.89 \mathrm{mg} / \mathrm{m}^{3}$ (range $0.55-4.06 \mathrm{mg} / \mathrm{m}^{3}$ ), and the mean respirable dust concentration $1.07 \mathrm{mg} / \mathrm{m}^{3}$ (range $0.16-1.55 \mathrm{mg}$ / $\mathrm{m}^{3}$ ). No significant difference was found between the concentrations in 1962 and 1971.

RESPIRATORY SYMPTOMS The prevalence of respiratory symptoms in 1962 is presented in Table I. No case of byssinosis was recorded. The prevalence of chronic cough and chronic bronchitis was higher among men than women but this was most probably due to a much higher frequency of smokers in the former $(60 \%)$ than in the latter $(4.3 \%)$ group. The prevalence of byssinosis, chronic cough, chronic bronchitis, and dyspnoea recorded in 1971 as compared with 1962 is presented in Table II. Only the results obtained in workers who worked in the mill in both 1962 and 1971 are included. The prevalence of byssinosis in men in 1971 was $20 \%$ (grade $1 / 2,1$ case ; grade 1, 2 cases) and in women $23 \%$ (grade $1 / 2,2$ cases; grade 1,1 case). The prevalence of all other respiratory symptoms was also

T A B L E I

PREVALENCE OF RESPIRATORY SYMPTOMS IN COTTON WOR KERS IN 1962

\begin{tabular}{|c|c|c|c|c|c|c|c|}
\hline Sex & No. & $\begin{array}{c}\text { Mean } \\
\text { Age } \\
\text { (yr) }\end{array}$ & $\begin{array}{c}\text { Mean } \\
\text { Expo- } \\
\text { sure } \\
(y r)\end{array}$ & $\begin{array}{l}\text { Chronic } \\
\text { Cough } \\
\text { No. } \%\end{array}$ & $\begin{array}{c}\text { Chronic } \\
\text { Bron- } \\
\text { chitis } \\
\text { No. } \%\end{array}$ & $\begin{array}{c}\text { Dysp- } \\
\text { noea } \\
\text { Grade } \\
2 \text { and } 3\end{array}$ & $\begin{array}{l}\text { Smoking } \\
\text { No. \% }\end{array}$ \\
\hline $\begin{array}{l}\mathbf{M} \\
\mathbf{F}\end{array}$ & $\begin{array}{l}20 \\
23\end{array}$ & $\begin{array}{l}27 \\
24\end{array}$ & $\begin{array}{l}2 \cdot 5 \\
1 \cdot 7\end{array}$ & $\begin{array}{ll}8 & 40 \cdot 0 \\
3 & 13 \cdot 0\end{array}$ & $\begin{array}{cc}4 & 20 \cdot 0 \\
0 & 0\end{array}$ & $\begin{array}{l}0 \\
0\end{array}$ & $\begin{array}{rr}12 & 60 \cdot 0 \\
1 & 4 \cdot 3\end{array}$ \\
\hline
\end{tabular}

T A B LE I I

PREVALENCE OF CHRONIC RESPIRATORY SYMPTOMS IN MALE AND FEMALE COTTON WORKERS IN 1962 AND 1971

\begin{tabular}{|c|c|c|c|c|c|c|}
\hline Year & Sex & $\begin{array}{l}\text { Bys- } \\
\text { sinosis } \\
\text { No. \% }\end{array}$ & $\begin{array}{l}\text { Chronic } \\
\text { Cough } \\
\text { No. } \%\end{array}$ & $\begin{array}{c}\text { Chronic } \\
\text { Bron- } \\
\text { chitis } \\
\text { No. \% }\end{array}$ & $\begin{array}{c}\text { Dysp- } \\
\text { noea } \\
\text { Grade } \\
2 \text { and } 3 \\
\text { No. \% }\end{array}$ & Smoking \\
\hline $\begin{array}{l}1962 \\
1971\end{array}$ & $\underset{(n=15)}{M}$ & $\begin{array}{cc}0 & 0 \\
3 & 20 \cdot 0\end{array}$ & $\begin{array}{ll}5 & 33.3 \\
6 & 40.0\end{array}$ & $\begin{array}{ll}3 & 20 \cdot 0 \\
5 & 33 \cdot 3\end{array}$ & $\begin{array}{cc}0 & 0 \\
5 & 33 \cdot 3\end{array}$ & 9 \\
\hline $\begin{array}{l}1962 \\
1971\end{array}$ & $(\mathrm{n}=13)$ & $\begin{array}{cc}0 & 0 \\
3 & 23 \cdot 0\end{array}$ & $\begin{array}{lr}1 & 7 \cdot 7 \\
4 & 30 \cdot 7\end{array}$ & $\begin{array}{ll}0 & 0 \\
1 & 7 \cdot 7\end{array}$ & $\begin{array}{cc}0 & 0 \\
3 & 23 \cdot 0\end{array}$ & 0 \\
\hline
\end{tabular}

increased in 1971 as compared with 1962, in both men and women. Owing to the small number of subjects available, the significance of differences was not tested.

VENTILATORY FUNCTION The mean changes of $\mathrm{FEV}_{0.75}$ over the first work shift in the week are presented in Table III. In men there was a significant decrease of $\mathrm{FEV}_{0 \cdot 75}$ over this shift in both $1962(\mathrm{P}<0.05)$ and $1971 \quad(\mathrm{P}<0.01)$. In women the mean acute decrease of $\mathrm{FEV}_{0.75}$ over the shift in 1962 was not statistically significant $(P>0.05)$, whereas in 1971 it was $(P<0.05)$. The mean acute decrease of $\mathrm{FEV}_{0 \cdot 75}$ over the work shift was higher in men than in women but the difference was not statistically significant $(P>$ $0 \cdot 05)$. The mean acute reductions of $\mathrm{FEV}_{0 \cdot 75}$

T A B L E I I I

FEV $_{0.75}$ CHANGES OVER WORK SHIFT IN COTTON WORKERS IN 1962 AND 1971

\begin{tabular}{c|c|cccc}
\hline \multirow{2}{*}{ Sex } & \multirow{3}{*}{ Year } & \multicolumn{4}{|c}{ FEV $_{0.75}(\mathrm{ml})$} \\
\cline { 3 - 6 } & & $\begin{array}{c}\text { Before } \\
1\end{array}$ & $\begin{array}{c}\text { After } \\
2\end{array}$ & $\begin{array}{c}\text { Difference } \\
1-2\end{array}$ & $P$ \\
\hline \multirow{2}{*}{$(\mathrm{n}=15)$} & 1962 & 3656 & 3570 & -86 & $<0.05$ \\
& 1971 & 3494 & 3271 & -222 & $<0.01$ \\
\hline \multirow{2}{*}{$\mathrm{F}(\mathrm{n}=13)$} & 1962 & 2736 & 2688 & -47 & $\mathrm{~ns}$ \\
& 1971 & 2645 & 2543 & -102 & $<0.05$ \\
\hline
\end{tabular}

ns $=$ difference statistically not significant $(P>0 \cdot 05)$.

were considerably higher in 1971 than in 1962. The difference between the mean reductions of FEV $_{0.75}$ over the shift in 1971 and 1962 was significant only in men $(P<0.05)$.

The mean reductions of $\mathrm{FEV}_{0.75}$ over the shift in byssinotics were considerably higher (men: $167 \mathrm{ml}$ in $1962,320 \mathrm{ml}$ in 1971 ; women: $85 \mathrm{ml}$ in $1962,120 \mathrm{ml}$ in 1971) than in workers without byssinosis in both 1962 and 1971 (men: $65 \mathrm{ml}$ in 1962, $198 \mathrm{ml}$ in 1971 ; women: $35 \mathrm{ml}$ in 1962, $97 \mathrm{ml}$ in 1971). 
Comparing the $\mathrm{FEV}_{0 \cdot 75}$ values measured before the first work shift in the week in 1962 and 1971, there was a slight fall of $\mathrm{FEV}_{0 \cdot 75}$ but this was not greater than expected with respect to the subjects' higher ages in 1971.

\section{DISCUSSION}

Although the mean mass concentration of total airborne dust in the mill $\left(1.89 \mathrm{mg} / \mathrm{m}^{3}\right)$ was higher than the suggested threshold limit value for cotton dust of $1 \mathrm{mg} / \mathrm{m}^{3}$ (Schilling et al., 1964 ; Roach and Schilling, 1960 ; American Conference of Governmental Industrial Hygienists, 1970) and in spite of a comparatively large proportion of respirable particles in the dust $(>50 \%)$, no case of byssinosis was found after exposure of one to three years. This is in agreement with the findings of Molyneux and Tombleson (1970) in their epidemiological study of respiratory symptoms in Lancashire cotton mills in which they observed that in mills processing coarse grade cotton workers developed symptoms of byssinosis within five years whereas in mills processing medium grade cotton workers developed symptoms of byssinosis only after 5 to 10 years' exposure. One would, therefore, expect an even longer latency period in workers exposed to fine grade cotton dust. The prevalence of other nonspecific respiratory symptoms (Table I) was not higher than that usually found in a population of the same age distribution and the same smoking habits (Žuškin, 1967 ; Šarić, Vukadinović, and Žuškin, 1966; Beritić, Pauković, and Valić, 1966).

Nine years later $20 \%$ of the men and $23 \%$ of the women had symptoms of byssinosis and the prevalence of all respiratory symptoms was increased (Table II). It could be argued that in smokers the increased respiratory symptoms might be the consequence of the nine-year longer smoking history, but all the women examined in 1971 were non-smokers, yet they showed an increased prevalence of respiratory symptoms.

Exposure to airborne fine grade cotton dust caused a significant mean acute reduction of FEV $_{0.75}$ over the first work shift in the week in 1962 only in men, whereas in 1971 much greater and significant mean reductions were observed in both men and women (Table III). These reductions were more pronounced in byssinotics (men, $320 \mathrm{ml}$; women, $120 \mathrm{ml}$ ) than in subjects without byssinosis (men, $198 \mathrm{ml}$; women, $97 \mathrm{ml}$ ). What is more important, the mean acute reduc- tion of $\mathrm{FEV}_{0 \cdot 75}$ over this shift in 1962 was significantly greater in the subjects who subsequently developed byssinosis $(127 \mathrm{ml})$ than in those who did not $(52 \mathrm{ml})$. The difference is statistically significant at the $1 \%$ level of confidence $(t=2 \cdot 89)$.

These findings made us analyse the individual falls of the forced expiratory volume over the shift in 1962 and to associate them with the subsequent development of byssinosis. As FEV $_{1 \cdot 0}$ is more frequently used today than $\mathrm{FEV}_{0.75}$, we have converted the measured acute decrease of $\mathrm{FEV}_{0.75}$ into $\mathrm{FEV}_{1 \cdot 0}$ values, using the conversion equation given earlier. Out of 28 cotton workers studied in 1962 and 1971, 26 $(93 \%)$ had a decrease of $\mathrm{FEV}_{1 \cdot 0}$ over the shift. In 18 of these 26 workers the $\mathrm{FEV}_{1 \cdot 0}$ reductions were less than $100 \mathrm{ml}$ in 1962 . No subject with an acute change of $\mathrm{FEV}_{1.0}$ of less than $50 \mathrm{ml}$ in 1962 and only one worker with a fall of 50-100 $\mathrm{ml}$ subsequently developed byssinosis. In contrast, five out of eight subjects $(60 \%)$ with a reduction of $\mathrm{FEV}_{1.0}$ greater than $100 \mathrm{ml}$ in 1962 had symptoms of byssinosis in 1971. It might therefore be argued that strong 'reactors' (Bouhuys et al., 1967) are so sensitive to the influence of histamine releasing agents in fine grade cotton dust that their $\mathrm{FEV}_{1.0}$ over shift work is reduced by more than $150 \mathrm{ml}$. In medium reactors the fall in $\mathrm{FEV}_{1 \cdot 0}$ over the first work shift in the week is $100-150 \mathrm{ml}$. It is the strong and medium reactors who are likely to develop byssinosis if they continue to be exposed to active airborne fine grade cotton dust.

Analysing the $\mathrm{FEV}_{0.75}$ changes over the shift in 1962, in 15 workers who left the mill before 1971 we found that the mean reduction of $\mathrm{FEV}_{0 \cdot 75}$ was considerably greater (men, $215 \mathrm{ml}$; women, $101 \mathrm{ml}$ ) than in those who were still working in the plant in 1971 (men, $86 \mathrm{ml}$; women, $47 \mathrm{ml}$ ). Of those 15 workers $26.7 \%$ would be considered strong and $13.3 \%$ medium reactors. It was the subjective feeling of chest tightness or breathlessness in the reactors that seems to have made at least some of them leave the cotton industry.

This investigation was supported in part by a grant (PL 480 Project 02-006-3) from the Bureau of Occupational Safety and Health, US Public Health Service, Department of Health, Education and Welfare.

\section{REFERENCES}

American Conference of Governmental Industrial Hygienists, Cincinnati, Ohio (1970). Threshold Limit Values of Airborne Contaminants. 
Beritić, C., Pauković, R., and Valić, F. (1966). Respiratory symptoms and ventilatory capacities in workers exposed to carbon black dust. $X V$ int. Congr. occup. Hlth, Vienna, 1966, Vol. 2, p. 689.

Bouhuys, A., Barbero. A., Lindell, S. E., Roach, S. A., and Schilling, R. S. F. (1967). Byssinosis in hemp workers. Arch. environm. Hlth, 14, 533.

McKerrow, C. B., McDermott, M., and Gilson, J. C. (1960). A spirometer for measuring the forced expiratory volume with a simple calibrating device. Lancet, 1, 149.

Molyneux, M. K. B., and Tombleson, J. B. L. (1970). An epidemiological study of respiratory symptoms in Lancashire mills, 1963-66. Brit. J. industr. Med., 27, 225.

Orenstein, A. J. (Editor) (1960). Proceedings of the Pneumoconiosis Conference, Johannesburg. Churchill, London.
Roach, S. A., and Schilling, R. S. F. (1960). A clinical and environmental study of byssinosis in the Lancashire cotton industry. Brit. J. industr. Med., $17,1$.

Schilling, R. S. F., Vigliani, E. C., Lammers, B., Valić, F., and Gilson, J. C. (1964). A report on a conference on byssinosis. XIV int. Congr. occup. Hlth, Madrid, 1963, Vol. 2, p. 137. Int. Congr. Ser. No. 62. Excerpta Medica Foundation, Amsterdam.

Šaric, M., Vukadinovič, D., and Žuškin, E. (1966). Epidemiological study of the prevalence of chronic bronchitis in selected groups of industrial population. $X V$ int. Congr. occup. Hlth, Vienna, 1966, 5, p. 97.

Wright, B. M. (1954). A size-selecting sampler for airborne dust. Brit. J. industr. Med., 11, 284.

Žuškin, E. (1967). Acute and chronic effects of vegetable dust in industrial exposures. Doctoral thesis, Zagreb University. 